\title{
Evaluation of Program for Overcoming Intestinal Worm Infections among Children
}

\author{
Henny Febriyanti, Haerawati Idris*
}

Department of Health Policy and Administration, Faculty of Public Health, Sriwijaya University, Indralaya, Indonesia

\begin{abstract}
Prevalence of intestinal worm infection in general is extremely high in Indonesia among the poor population with poor sanitation. One of the government programs to address this problem is the distribution of medicines to prevent intestinal worm infections. However, the coverage of the achievement for this program is still low in several areas of public health centers in Palembang. Therefore, this study was conducted to evaluate the efficacy of the national program for preventing intestinal worm infections. The qualitative research design used evaluation model approach Context, Input, Process, and Product (CIPP) model. This study was conducted in one of health centers in Palembang City. The informants were selected using purposive method. Data collection was done via in-depth interviews, document reviews, and observations. Descriptive content analysis was used to examine and process the collected data. Results showed that, from situational factor, the program is held by the government because of the high prevalence of intestinal worm infection. The study found the input component, limited staff that handles this program. There were limited facilities for the extension of the infrastructure. In the process component, the distribution of the drug albendazole was not optimal in all elementary schools. Four elementary schools did not receive albendazole. This study demonstrated that the implementation of the program was not optimal.
\end{abstract}

Keywords: drug distribution, evaluation, worm infection

\section{Introduction}

Soil-transmitted helminth infections are among the most common diseases worldwide and affect the poorest and the most deprived communities. These infections spread through the eggs present in human feces in areas with poor sanitation. ${ }^{1}$ Soil-transmitted helminth infections of humans are included within the World Health Organization (WHO) classification and termed as neglected tropical diseases. The maximum proportion of these infections has been reported among the population of Southeast Asia. ${ }^{2}$

More than two billion people are infected with worms throughout the world, and 300 million people suffer from helminth infection (helminthiasis), which leads to the death of 150,000 people due to infections with soiltransmitted helminth infections. ${ }^{3}$ The global prevalence of anemia in school-age children shows a high rate of approximately $37 \%$, whereas it is $13.4 \%$ in Thailand and $85.5 \%$ in India; the prevalence of anemia among children in Asia reaches around $58.4 \% .4$

A test for helminthiasis is considered to be positive

Correspondence*: Haerawati Idris, Faculty of Public Health, Sriwijaya University, Raya Palembang-Unsri KM 32 Indralaya Street, Ogan Ilir, Indonesia, Phone: +62 711580068, E-mail: haera@fkm.unsri.ac.id when worm eggs or at least one type of worm is observed in the specimen. Soil-transmitted helminth worm infections are widely found in primary school-age children. ${ }^{5}$ A recent study reported that more than 267 million preschool-age children and more than 568 million school-age children live in areas where these parasites are intensively transmitted and require treatment and preventive interventions. ${ }^{6}$ School-age children also have the highest class infected with worms that spread through the soil. There are several cases of intestinal worms from Ascariasis worms. Soiltransmitted helminth infections can occur through the ingestion of worm eggs from the ground or ingestion of active larvae in the soil through the skin. ${ }^{7}$

Worm infection is an endemic disease caused by parasites that not only can be deadly, but also undermine the health of the human body, which can thereby reduce the nutritional status and health of the population. ${ }^{8}$ Factors that are responsible for the high rates of helminthiasis include inadequate environmental sanitation conditions, poor personal hygiene, education level, 
low economic conditions, knowledge of attitudes and behavior toward uncultured healthy living, and geographical conditions suitable for worm breeding. ${ }^{9}$ Worm infections are one of the neglected diseases, so that there is less attention toward both prevention and treatment. ${ }^{8}$

Intestinal worm infections still represent a widespread public health problem in most parts of Indonesia, which can in turn reduce the nutritional status, intelligence, and productivity of the population. Efforts made to reduce intestinal worm infections are primarily focused on children aged $<5$ years. Schools must be empowered with community programs and cross commitments sector. The government made the Regulation of Health Minister No. 15/2017 to eradicate helminthiasis. ${ }^{9}$ Evaluation aims not to prove the fault of a program, but to improve the program and the importance of this program as a decrease in the number of helminthiasis in children that has an impact on reducing health conditions and reducing intelligence in children. It is necessary to conduct an evaluation of the implementation of worm mass prevention drug delivery programs in children school. ${ }^{10}$ The aim of this study was to evaluate the program for reducing the burden of intestinal worm infections using evaluation model approach CIPP (context, input, process, and product) model.

\section{Method}

This study used a qualitative study design using the context, input, process, and product (CIPP) model evaluation approach. ${ }^{10}$ The model was used to evaluate the program. It was evaluated based on Regulation of Health Minister No. 15/2017 for reducing the burden of intestinal worm infections. In this context, the study evaluated the background of the program and its goals and objectives. In the input component, the study evaluated the human resources, infrastructure, budget funds, and management information system. In the process component, the study evaluated the planning, implementation, monitoring, and evaluation of the program. In the product component, the coverage of achievement of the program was evaluated.

This investigation was a descriptive study, aimed at obtaining in-depth information to determine the problems clearly and understand the meaning behind the data or information derived, which in this case was regarding the evaluation of worm disease prevention programs. ${ }^{11}$

The study informants consisted of one head of the Pemberantasan Penyakit Menular / P2M (Eradication of Infectious Disease) City Health Office, one head of the Primary Health Care, one holder of the program for the administration of helminthiasis, and one pharmacist. The supporting informants were derived from elementary school-age children who were selected, considering that the informants had the required information and were involved in the implementation of worm mass prevention medicines. This study was conducted at one primary health care in Palembang City from May to June 2018.

Data collection was done through in-depth interviews with some informants regarding the implementation of the program, observation of the facilities and the process of the program, and reviewing the guidelines and documents tailored to the type of data. A document study was conducted to check the completeness of data related to the schedule of administering the worm mass prevention medicines and program achievement data. Indepth interviews were conducted with key expert informants (Head of the P2M division, head of the primary health care, and worm program holder and primary health care pharmacy officer) and supporting informants (some children from elementary schools), observing the facilities of the program.

The study observed the availability of albendazole or deworming medicines and also the promotional facilities such as leaflets, counseling booklets, and posters. Supporting data were obtained from document studies or archives related to the implementation of helminthiasis prevention programs among schoolchildren. Then the study created a table to input the information and perform a checklist with sign $(+)$ that indicates available and $(-)$ indicating unavailable.

The supporting informant was used for triangulation data analysis. The study obtained some information about the implementation this program in elementary schools. The information was on the distribution of the medicine albendazole in schools. Data processing was conducted using content analysis. ${ }^{12}$

Data validity was evaluated using data triangulation. Triangulation is a technique of checking the validity of data that uses something else outside the data to check data or as a comparison to the data. ${ }^{13}$ The triangulations conducted in this study were source triangulation, method triangulation, and theory triangulation.

Data analysis was conducted after all the data were collected and processed. The contents of the data were analyzed. Qualitative data analysis was related to data reduction, data categorization, synthesis, and working hypothesis. ${ }^{13}$ The results of this study in the form of data processing are presented in the form of matrices and narratives. For the results of the study to be detailed, objective, and neutral, quotations from the informant's statement in the original form to describe the results of the study were added. This study was equipped with interview matrices, which were arranged and grouped based on questions and variables to facilitate understanding and conclusion. Before conducting this study, ethical 
approval was obtained from the ethical institution at the Faculty of Public Health, Sriwijaya University, with the Number 106/UN9.1.10/KKE/2018.

\section{Results}

The implementation of administering worm mass prevention medications is represented in the form of an explanation description using the CIPP evaluation model, which includes context, input, process, and product (Table 1).

Findings in the field of the context component included the background of the program and its goals and objectives. The goal of establishing this helminthiasis program was to reduce the number of helminthiasis cases among schoolchildren. The environmental conditions of each primary school were undoubtedly different, that was, if viewed from a distance, there were elementary schools that near people's homes, but there were also elementary schools in remote areas or away from the crowd, so that it takes approximately 15 minutes to reach the school. There were also still several elementary schools whose environment was inappropriate due to swamp conditions, presence of excess garbage and unpleasant smell, and lack of hygienic sanitation, which are included in the category of slums, clean and healthy lifestyle in the school environment have not been applied "So, the policies and concern underlining why this program of helminthiasis prevention medicines is essential to give is that because the prevalence of helminthiasis in school-aged children is quite high at around $30 \%$ [...] because this is a disease related to environment, water, with PHBS (clean and healthy lifestyle), with handwashing, of course this will be a very high case of intestinal worms in areas with poor hygiene sanitation. The poor hygiene sanitation is like the slum, the dense, areas where water distribution is not feasible." (IK 1)

Based on the document review conducted on the Ministerial Regulation on the provision of helminthiasis prevention drugs included in the policy of situational factors, according to Regulation of the Minister of Health No. 15 of 2017 concerning worm prevention that the prevalence of intestinal worms at 20\% - 50\% must administer worm mass prevention medicines once a year.

Each program certainly has an objective/target. The target of this worm disease prevention program is all children aged $6-12$ years, and the role of the cross-sector is very much required for administering helminthiasis medicines to achieve the goals of the program.

"The goal was, school-age children (6-12 years) conclusions for all children aged 6 to 12 years." (IK 1 )

If viewed from the above-described background, the

Table 1. Results of Observation on Mass Drug Administration for the Prevention of Helminthiasis

\begin{tabular}{|c|c|}
\hline Component & Primary Health Care \\
\hline \multicolumn{2}{|l|}{ Context } \\
\hline There is a policy on administering mass worm disease prevention drugs & + \\
\hline There is the purpose of providing mass worm disease prevention drugs & + \\
\hline There is a target of providing mass worm disease prevention drugs & + \\
\hline There is environment support of administering mass worm disease prevention drugs & + \\
\hline \multicolumn{2}{|l|}{ Input } \\
\hline Specifications of education with occupation in the implementation of worm disease prevention programs & + \\
\hline The number of human resources with standards in the implementation of worm disease prevention programs & - \\
\hline The existence of training in the effort to provide worm disease prevention drugs & + \\
\hline $\begin{array}{l}\text { The utilization of health operational assistance funds for the implementation of activities for administering } \\
\text { worm disease prevention drugs }\end{array}$ & + \\
\hline Adequate allocation of funds to carry out the program & + \\
\hline There is evidence of accountability for the use of funds in the implementation of the program & - \\
\hline Guidebook for administering mass prevention drugs for health workers & + \\
\hline The existence of promotional media such as posters, leaflets, and brochures & - \\
\hline The presence of a management information system in the program of administering worm disease prevention drugs & + \\
\hline Is the benefit of information systems running well & + \\
\hline \multicolumn{2}{|l|}{ Process } \\
\hline Having data on the amount of worm disease participants in each elementary school according to gender and age & - \\
\hline Having data on the number of elementary schools & + \\
\hline $\begin{array}{l}\text { Preparing the team as the person in charge and implementing the program of administering mass worm disease } \\
\text { prevention drugs }\end{array}$ & + \\
\hline Cross-sector-related socialization to obtain support and initial efforts to form partnerships & + \\
\hline Schedule of activities & + \\
\hline Letter of assignment in the implementation of the worm disease prevention program & - \\
\hline The recapitulation of the activity implementation report & + \\
\hline Documentation of the implementation of activities & - \\
\hline $\begin{array}{l}\text { Monitoring various internal factors (e.g., officers, planning, infrastructure) to carry out the activities of } \\
\text { administering mass worm disease prevention drugs }\end{array}$ & + \\
\hline Monitoring the progress of the implementation of the activities of providing mass worm disease prevention drugs & + \\
\hline \multicolumn{2}{|l|}{ Product } \\
\hline Data on target programs for administering mass worm disease prevention drugs & + \\
\hline Achievement data of administering mass worm disease prevention drugs & + \\
\hline Data on the socialization of worm disease mass prevention drugs program & + \\
\hline
\end{tabular}

Note: + (available), - (unavailable) 
aim of this worm disease prevention program is to reduce the number of worms in children.

"The goal is clear with the provision of this worm mass prevention drug in the hope that it will reduce the rate of helminthiasis in children aged 6 to 12 years and prevent stunting. " (IK 2)

Based on the observation results, theaim of this program refers to Regulation of Health Ministry No. 15 of 2017 regarding Worm Tackling. The program has general and specific goals. The general goal is to reduce the prevalence of intestinal worms in elementary schoolage children. The first specific objective is to reduce the prevalence of intestinal worms in primary schoolchildren by $10 \%$ in stages, and the second objective is to increase the achievement of coverage of the provision of deworming mass prevention medicines by at least $75 \%$. Therefore, it can be concluded that the precise aim of this program is to reduce the number or the prevalence of helminthiasis cases among children aged $6-12$ years (Table 2).

Field findings on the input component are human resources, infrastructure, budget funds, and management information systems. Resources are precious assets to achieve a goal. Quantitatively, there were one officer and manager of the Mass Drug Administration for the Prevention of Helminthiasis, as well as the officer providing the Mass Treatment of Helminthiasis.

"... there was one program manager at the primary health care,

one PNS (civil servant), and the officer of Helminthiasis

Prevention Program for mass prevention..." (IK 3 )

For human resources in the program for administering the helminthiasis mass prevention medicines, there was no standard for the quantity or number of program management officers.

"The program officer is one person [...] that officer [...]" (IK

Table 2. Summary of Qualitative Study Results on the Context Component in Administering Mass Worm Disease Prevention Medicines

\begin{tabular}{ll}
\hline Variable & Study Result \\
\hline Background & $\begin{array}{l}\text { Ministry of Health Regulation, Republic of Indonesia, } \\
\text { Number 15 of 2017 regarding worm prevention }\end{array}$ \\
Target & $\begin{array}{l}\text { The target of this program is all children aged 6-12 years } \\
\text { To reduce the prevalence or rate of worms in children aged } \\
\text { 6urpose }\end{array}$ \\
&
\end{tabular}

4)

The facilities and the infrastructure contained in this program are not extensive according to the statement of the informants of the facilities and the support provided in the program for administering these worm mass prevention drugs.

“... especially medicines, your albendazole, then supported by facilities and infrastructure, such as for promotion, promoting programs for administering helminthiasis mass prevention medicines, such as leaflets, booklets, and posters." (IK 1)

According to the results of observation through the observation sheet, the study found only albendazole or deworming medicines, and other promotional infrastructure facilities, such as leaflets, booklets, and posters were not found as they were unavailable in this program. Another promotional infrastructure was only through counseling. Thus, the facilities and the support in this program are still inadequate or not optimal as there are still limited facilities for the extension of the infrastructure.

Funds are limited resources required to support the implementation of a program. The sources of funds for Mass Drug Administration for the Prevention of Helminthiasis programs came from State Budget and Revenue, Regional Budget, and other legitimate funding sources; however, in this program, there are no funds in the primary health care because it receives only helminthiasis medicine and the primary health care will later take it to the pharmacy warehouse, but for the primary health care, it is necessary to take funds.

"The source of funds for the worm prevention Bulk Drug

Provision program comes from the State Budget and Revenue,

Regional Budget, and other legitimate funding sources. If our personnel takes it from the health operational assistance funds

[...] if the helminthiasis medicine comes from the office, it might be from the (Health) Ministry [...] it is from the office [...] because the helminthiasis medicine is already programmed." (IK 2)

The funding for this program was derived from the National Budget, the Regional Budget, and other legitimate funding sources for the 2017 Mass Drug Administration for the Prevention of Helminthiasis delivery program in the form of meetings, training,

Table 3. Summary of Qualitative Study Results on the Input Component in Administering Mass Worm Disease Prevention Medicines

\begin{tabular}{ll}
\hline Variable & Result \\
\hline Human resources & $\begin{array}{l}\text { The number of human resources in administering mass worm disease prevention medicines for one program holder and con } \\
\text { currently serves as an officer. }\end{array}$ \\
$\begin{array}{l}\text { Diploma III in Midwifery educational background } \\
\text { The availability of albendazole } \\
\text { Facility and infrastructure }\end{array}$ & $\begin{array}{l}\text { The limitations of extension of infrastructure facilities such as leaflet, booklet, and poster, as they do not yet exist } \\
\text { The funds for administering mass worm disease prevention medicines were derived from the National Budget, the Regional } \\
\text { Budget, and other legitimate sources. } \\
\text { Transport funds for program officers following the policies of primary health care } \\
\text { There are differences in results, and the information obtained is less accurate }\end{array}$ \\
\hline
\end{tabular}


implementation, monitoring, and evaluation of worm disease prevention programs. The management information system is an application program created to help primary health care to manage quickly and easily. An optimal implementation of information systems has the potential to reduce workload and increase time efficiency (Table 3).

"Yes, every report from each primary health care is inputted. If

it does not use the information system in other forms of data,

(the report) can be lost [...] in the department, (there are) also

many programs, not only program for helminthiasis." (IK 1)

Variables in the process component are preparation, implementation, monitoring, and coaching of the program. Preparation of albendazole medicine distribution that albendazole medicine in the Provincial Health Office or the City Health Office enter the pharmaceutical warehouse, each primary health care officer takes the albendazole medicine directly to the pharmaceutical warehouse in accordance with the targets previously reported.

"Our preparation is only once every six months; the most wide-

ly prepared is to receive the helminthiasis medicine from the

target and the target." (IK 2)

The component of the implementation process of the worm intestinal mass prevention medicines delivery program is the first to distribute existing medicines, before distributing the medicines, of course, socialization. Officers from the primary health care immediately visited each target in the work area of each primary health care to distribute albendazole or the deworming medicine according to the target amount. Officers or program holders go to primary schools that are the target of the program; there are elementary schools that are receive albendazole from health workers, and there were also elementary schools that receive albendazole from teachers at primary schools.

"For the implementation carried out by us at this primary health care we immediately go to elementary school to give albendazole medication, all children aged 6 to 12 years must get this albendazole medicines." (IK 2)

Monitoring and coaching are vital functions in the implementation of a program to identify the problems and the efforts that will be implemented subsequently.

"Supervision on us comes. There is a monthly Minlog meeting

(mini workshop), so (in) each our meeting, (we) talk about the

programs of each of us shown, so they know." (IK 1 \& 2)

Monitoring and coaching were conducted by the Palembang City Health Office, namely supervision, directly at the primary health care which has the results not yet according to the target set. In Padang Selasa Primary Health Care in Palembang, monitoring and coaching are conducted in the form of a monthly Minlog meeting to discuss each work program. The results of the interview regarding the constraints or obstacles that exist in the Padang Selasa Primary Health Care in this program showed that there were no obstacles or constraints in the program of administering helminthiasis medicines.

The results of the coverage that existed in the program of providing helminthiasis prevention medicines, which was the target of the achievement and to improve the next program hence existing programs can run better.

"(It is) already achieved, following the target of 100\%." (IK

2)

Based on the results of interviews, there was $100 \%$ achievement of the helminthiasis mass prevention program. However, a difference was observed after a cross-check on schoolchildren to assess whether the results of the worm prevention program were consistent with the $100 \%$ achievement.

According to 16 informants, the study took from each primary school as representatives. There were still four elementary schools that did not receive albendazole or the worm medicines. This implies that the distribution of albendazole has not reached $100 \%$, or it could be said that it did not meet the standard targets that had been set.

\section{Discussion}

Management planning functions for an action or a program must include information about what, why, when, where, who, and how the program is going to be implemented. ${ }^{13}$ The policy environment is a component that can support a condition or an outcome of a policy, a situation associated with a problem that leads to the formation of the policy. There are four factors that influence a system, namely situational factors, structural factors, cultural factors, and environmental factors. Based on this theory, the study program of mass helminthiasis prevention medicines administration was included in the policy of situational factors. This is in accordance with the Regulation of the Ministry of Health No. 15 of 2017 pertaining to Worm Control, mentioning that the prevalence of intestinal worms is $20 \%-50 \%$, which is an alert to administer worm mass prevention medicines once in a year. Personal hygiene includes the cleanliness of the skin, head and hair, eyes, nose, ears, nails, and toenails and the hygiene of all parts of the body. ${ }^{14}$ The importance of personal hygiene has been emphasized by the Law Number 23 of 1992 Article 3 concerning health, stating that, "Everyone must participate in improving and maintaining the health status of individuals, their families and the environment.". 15

Each health program has a target group, namely to whom the health program is shown. ${ }^{16}$ The target is a particular community group that will be investigated by the planned program. ${ }^{17}$ A program is said to be useful when the objective has been achieved. ${ }^{18}$ If compared with the Deworming Drug Prevention Distribution 
Program for School-Age Children, this program is said to be effective because the objective in this program is clear, that is, all children aged 6-12 years or elementary schoolchildren in grades 1-6 targeted.

Determining the goal is a function to measure the success of a program's activities. ${ }^{19}$ The overall objectives can be divided into broad goals and specific objectives. The goal, in general, must have a clear relationship with the mission of the organization, namely the problems to overcome and the description of the conditions to achieve. ${ }^{20}$ The aim of this Mass Drug Administration for the Prevention of Helminthiasis is relevant to the background of the establishment of mass deworming prevention medicines.

The division of labor implies the process of division of work tasks from the whole to be more specific or simple and detailed. The entire work is divided based on specific criteria and is more accurate. ${ }^{21}$ Compared to the provision of mass helminthiasis prevention medicines, the division of labor was implemented based on the educational background and the ability of the staff at the primary health care. However, there were no more specific criteria. The role of stakeholders is required in running a deworming control program because, while carrying out this program with sufficient budget, adequate facilities and trained human resources are required. Therefore, the target of program implementation can be achieved according to the target set. ${ }^{8}$

The availability of facilities, infrastructure facilities, tools, and materials had already supported the mass helminthiasis prevention medicines distribution program to the level of health centers. The existence of distributed leaflets was an effort to support the program, but no counseling efforts were made either directly or through printed and electronic mass media. Counseling is an effort to empower individuals, groups, and communities to maintain, improve, and protect public health. Based on the results of observations and interviews, the facilities and infrastructure contained in this program were not optimal. Some facilities and infrastructure provided only albendazole, and other infrastructure facilities were unavailable. Only counseling was implemented before the program. ${ }^{8}$

Costs involved in a plan vary extremely depending on the type and number of activities carried out. Inclusion of costs should be completed with details, such as personnel costs, operational costs, costs of facilities and infrastructure or facilities, assessment costs, and development costs. ${ }^{20}$

Funding sources for the Mass Drug Administration for the Prevention of Helminthiasis were from State Budget and Revenue, Regional Budget, and other legitimate sources of funds used for the 2017 program in the forms of meeting, training, implementation, monitoring and program evaluation. For information in details, the study had not yet received information on allocation fund because informants on this study did not deliver further information; while, the primary health care did not receive funds for this program because the primary health care only received helminthiasis medicine or albendazole in accordance with the target. However, for the primary health care officers, they need to manage transport funds in appropriate with each primary health care.

Enhancement of technological information could increase access in making the work load easier. Primary Health Care Management Information System usage provides convenience and produces accurate information; data search becomes more rapid, and the manufacturer can provide faster reports with uniformity. ${ }^{22}$ Quality system information should meet some terms, including the completeness, accuracy, time precision, relevance of the report, and reliability for use every time with data that are always updated. ${ }^{23}$ Based on observation, the primary health care has already implemented management information system for the program. It helps ease the reporting and the evaluation of monthly mini workshop.

A worm eradication program consists of health promotion, worm surveillance, control of risk factors, managing the sufferers, and providing bulk medicines for worm prevention. Based on book guidelines for the eradication of worms, the program describes that, before the implementation of administering medicines for preventing worm infections, it is first necessary to implement activities such as counseling corresponding with book guidelines, although the activities not obtained document on during activities. ${ }^{24}$ This study is in line with Mass Drug Administration for the Prevention of Helminthiasis research program at which counseling is needed before the implementation of the program, thus the program can be more effective and in line with the plan.

Evaluation was carried out in stages to monitor which stages were running smoothly and which steps were experiencing obstacles in the implementation, so that the development carried out in the framework of achieving the goals has been formulated. ${ }^{25}$ Compared with the theory, the implementation of evaluation activities for worm mass prevention programs was specifically not done at stages, but overall, making it challenging to monitor constraints in the implementation of this program. The regulation of the Ministry of Health of the Republic of Indonesia Number 15 of 2017 states that one of the medicines used for deworming is albendazole.

Obstacles or constraints that exist in the program of administering worm mass prevention medicines include late acceptance from schools and administration of 
worms or albendazole. This is a constraint for this program. Another obstacle is that this program is still new, thus it takes time to improve and socialize.

The major obstacles that often arise in the implementation of government programs or policies are fostering vertical cooperation, developing horizontal working relationships, and overcoming the problem of rejection of changes that arise from the community. 26 The values strong of local culture and weak relationships and social support can cause ineffectiveness in a program. ${ }^{27}$

The management system is linkages between context, input, process, and output. In one perspective, it is known that one variable to another is related, hence, it can affect a program become not in accordance with the target. The results of interview with other informants obtained that there were still many informants that had not known yet about the helminthiasis program and there were school children that had not yet received a helminthiasis medicine or albendazole. Therefore, it could be concluded that the result of coverage of Mass Drug Administration for the Prevention of Helminthiasis was not yet in accordance with the determined standard target.

\section{Conclusion}

The study evaluates the program implemented for reducing the burden of intestinal worm infections. The study finds that, in the input component, there is limited staff who handle this program. There are limited facilities for the extension of the infrastructure. In the process component, the distribution of albendazole was not optimal at all elementary schools. There are four elementary schools that have not received albendazole. In addition, the program coverage achievement is lower than the standard. It is suggested that the government should improve the supervision of the distribution of albendazole at every elementary school.

\section{Abbreviations \\ CIPP: Context, Input, Process, and Product; WHO: World Health Organization; P2M: Pemberantasan Penyakit Menular; PHBS: Perilaku hidup bersih dan sehat}

\section{Ethics Approval and Consent to Participate}

Ethical approval was obtained from the ethical institution at the Faculty of Public Health, Sriwijaya University, with the Number 106/UN9.1.10/KKE/2018.

\section{Competing Interest}

Author declares that there are no significant competing financial, professional, or personal interests that might have affected the performance or presentation of the work described in this manuscript.

\section{Availability of Data and Materials}

The data that support the findings of this study are available from the corresponding author upon reasonable request.

\section{Authors' Contribution}

Henny Febriyanti: project administrator, study designer, data curator, analysis, and original draft; Haerawati Idris: study designer, data curator and analysis, supervision, writing - original draft, writing - review and editing. All authors have read and approved the final manuscript.

\section{Acknowledgment}

We would like to express our gratitude to Padang Selasa Primary Health Care for giving us permission to do the study.

\section{References}

1. World Health Organizations. Intestinal worm; 2019.

2. Dunn JC, Turner HC, Tun A, Anderson RM. Epidemiological surveys of, and research on, soil-transmitted helminths in Southeast Asia: a systematic review. Parasite Vectors. 2016; 9(1): 31.

3. Noviastuti AR. Infeksi soil transmitted helminths. Jurnal Majority. 2015; 4(8): 107-16.

4. Sirajuddin S, Masni M. Kejadian anemia pada siswa sekolah dasar. Kesmas: National Public Health Journal. 2015; 9(3): 264-9.

5. Kartini S. Kejadian kecacingan pada siswa Sekolah Dasar Negeri Kecamatan Rumbai Pesisir Pekanbaru. Jurnal Kesehatan Komunitas. 2016; 3(2): 53-8.

6. World Health Organizations. Soil transmitted helminth infection. [serial on the Internet]. 2019 [cited 2018 Jun 1].

7. Hanif DI, Yunus M, Gayatri RW. Gambaran pengetahuan penyakit cacingan (helminthiasis) pada wali murid SDN 1, 2, 3, dan 4 Mulyoagung, Kecamatan Dau, Kabupaten Malang, Jawa Timur. Preventia. 2017; 2(2).

8. Juhairiyah J, Annida A. The policy of helminthiasis control and public knowledge againts helminthiasis in banjar regency South Kalimantan Province. Buletin Penelitian Sistem Kesehatan. 2014; 17(2).

9. Marlina L, Widjaja J. Hubungan pendidikan formal, pengetahuan ibu dan sosial ekonomi terhadap infeksi soil transmitted helminths pada anak sekolah dasar di Kecamatan Seluma Timur Kabupaten Seluma Bengkulu. Indonesian Journal of Health Ecology. 2012; 11(1).

10. Kementerian Kesehatan RI 2017. Peraturan Menteri Kesehatan Republik Indonesia no. 15 tahun 2017 tentang penanggulangan kecacingan. Jakarta; 2017.

11. Widoyoko EP. Evaluasi program pembelajaran. Yogyakarta: Pustaka Pelajar; 2009.

12. Nugrahani F, Hum M. Metode penelitian kualitatif. Solo: Cakra Books; 2014.

13. Syafrudin SK. Organisasi dan manajemen pelayanan kesehatan dalam kebidanan. Jakarta: Trans Info Media; 2009.

14. Tarwoto, Wartonah. Kebutuhan dasar manusia dan proses keperawatan. Jakarta: Salemba Medika; 2010.

15. Moleong LJ. Metodologi penelitian kualitatif. Bandung: Remaja Rosdakarya; 2010.

16. Maulana HD. Promosi kesehatan. Jakarta: EGC; 2009.

17. Azrul A. Pengantar administrasi kesehatan. Jakarta: Binarupa Aksara; 
2010.

18. Ryadi AL. Ilmu kesehatan masyarakat. Yogyakarta: Penerbit Andi; 2016.

19. Yandana NA. Efektivitas kerja sama koperasi syariah beriman dengan yayasan yatim mandiri dalam program bunda yatim sejahtera.

Doctoral Dissertation. Surabaya: UIN Sunan Ampel Surabaya; 2014.

20. Saleha MF, Satrianegara M. Buku ajar organisasi dan manajemen pelayanan kesehatan serta kebidanan. Jakarta: Salemba Medika; 2009.

21. Fajar NA. Modul Mata kuliah perencanaan dan evaluasi PKM. Fakultas Kesehatan Masyarakat. Indralaya: Universitas Sriwijaya; 2010.

22. Wijayanto D. Pengantar manajemen. Jakarta: Gramedia Pustaka Utama; 2013.

23. Wibisono S, Munawaroh S. Sistem informasi manajemen puskesmas (Simpuskesmas) berbasis cloud computing. Dinamik. 2012; 17(2).
24. Isma SL, Sudaryanto S, Halleyantoro R. Evaluasi program pemberantasan kecacingan pada siswa Sekolah Dasar di Puskesmas Rowosari Kecamatan Tembalang Semarang. Jurnal Kedokteran Diponegoro. 2019; 7(2): 551-61.

25. Mustari M, Rahman MT. Manajemen pendidikan. Jakarta: Raja Grafika Persada; 2014.

26. Mubarak A. Model impelementasi program dalam upaya pencapaian sasaran MDGS 2015 (strategi bagi birokrasi sebagai ujung tombak implementasi 8 sasaran MDGS). 2012 [cited 2018 Jun 1].

27. Imron A. Implementasi kebijakan kesehatan "LIBAS 2+" sebagai upaya menurunkan angka kematian ibu dan bayi di Kabupaten Sampang. Jurnal Kebijakan Kesehatan Indonesia. 2013; 2(3): 107-111.

28. Departemen Kesehatan Republik Indonesia. Sistem Kesehatan Nasional. Peraturan Presiden Republik Indonesia Nomor 72; 2009. 